\title{
MUGHALS and KASHMIR with its ECONOMY
}

\section{(1586-1752 AD)}

\section{Dr.Manzoor Ahmad}

\begin{abstract}
Kashmir constituted a significant unit of the mighty Mughal Empire. The Valley stood in the neighborhood of Kabul province which touched the borders of Central Asia. Multan and Lahore exist to its south and remained in connection with Punjab by various routes. The Valley experienced the rule of great rulers of the dynasty like Akbar, Jahangir, Shah-i-jahan and Aurangzeb. The occupation of the land by the Mughals ended its age long internal strife, provided uniform system of administration, abolished toll tax, improved and extended its routes, which together boosted the trade and commerce of the territory. Further the restoration of peace and noval changes introduced in the agrarian set up rehabilitated the shattered economy of the state. Though it immuned the rulers of the territory to spent their enormous wealth on the construction of monuments, gardens, development of health resorts and inns which in homogenous nature turned the land in the words of Mughal Emperor Jahangir a "Paradise on earth", yet in the concluding epoch under its weak rulers e.g. Mohammad Shah (1719-1748) the Valley passed through agony especially the peasantry suffered due to the callous attitude of the revenue functionaries and the prevalent horrible taxation system.
\end{abstract}

Keywords: - Paradise, Mir-i-Aab (water-distributor),Kharif(Autumn crops), Rabi(Spring crops, Kashta (ploughed), Uftada (unploughed),callous,Subedar,Khalisa,jagir,Maded-i-Mash,Karkhana.

\section{INTRODUCTION}

The Mughal sovereigns of India had their covetous eye on Kashmir since the founder of the dynasty Babar, who tried to annex Kashmir but failed in his attempt. No doubt his son Kamran conquered the land in 1531 A.D but retained it for a brief period of two months ${ }^{1}$. It was in 1540 Humayun who succeeded Babar received invitation from the nobles of Kashmir to conquer the territory, but being fugitive at Lahore due to his debacle with Sher Shah Suri of India authorized his relative Mirza Haider Dughlat to accept the invitation. Mirza Haider marched towards the land and easily succeeded in expelling Nazuk Shah the then ruler of sultanate period with a meager force of three hundred men at his back. He held the reigns of the territory till his death in 1552 and continued Nazuk Shah as a titular ruler to the land $^{2}$. In 1555 A.D India again witnessed the Mughal rule as Humayun had defeated the Pathan rulers of Suri dynasty. In 1556 Akbar the great succeeded Humayun as the ruler of India,who after the consolidation of his rule began to interfere with the affairs of Kashmir. Accordingly in 1560 he deputed Qarabahadur to annex Kashmir as appealed by the Kashmiri nobles owing to internal strife, but changed his view later on. This led the Sultans of Kashmir to send rich gifts to the Mughal Emperor who considered the same as tribute and recognition of his supreme authority ${ }^{3}$ as Samudra Gupta (335375 AD) of Gupta Dynasty did in relation to the southern states of India. The Sultans of Kashmir were replaced in 1561 by Chak rulers who were of Shia sect, while as the masses belong to Sunni faith. The period from 15611586 under Chak rule witnessed a communal tension which disturbed peace and order in the territory for decades together. Consequently Sultan Ali Shah who ascended the throne in 1570 and introduced himself to his subjects publically in a mass gathering at Jamia Masjid Srinagar. Though he promised of fair administration yet the communal conflict continued, which forced his successors to beg for help to its neighbours. The situation provided the outsiders an opportunity to intervene. Consequently in 1573 Akbar sent two ambassadors, Mulla Ishaqi and Qazi Sadurr-ud-din to the court of Sultan Ali Shah (1570-78). Though their object of visit was to negotiate a marriage between a Kashmiri princess and prince Saleem(Jahangir) yet they had come to assess the possibility of the Mughal conquest of Kashmir. In conversation of matrimonial alliance, the ambassadors revealed the notion which deeply impressed the Sultan. He not only accepted the matrimonial alliance but also 
read Khutba and struck coins in the name of Akbar. This activity cleared that Ali Shah had accepted the Mughal suzerainty ${ }^{4}$, as he considered himself no match before Akbar the Great of the Mughals dynasty.

Ali Shah Chak the ruler of Kashmir in his lifetime had declared Yusuf Khan his son as successor, but after his death Abdal Chak his brother refused it. The event led an open battle between the two at Nauhatta Srinagar where Abdal Chak was killed and Yusuf khan came out victorious. Consequently in 1578 he ascended the throne under the title of Nasir-u-Din Mohammad Yusuf Badshah Ghazi. But it is irony of fate that the king being a romantic figure spent maximum time in the company of women. So a close associate of Sultan Ali Shah, Syed Mubarak Baihaqi duly supported by Abdal Bhat launched a revolt against the ruler. It led a hard contest for power between the two at Eidgah Srinagar. The rebels in the event came out victorious and Yusuf Shah Chak fled to Thana in $1579^{5}$. Though Syed Mubarak Baihaqi ascended the throne in 1579 A.D yet after a brief period of 6 month was compelled by the Chak nobles to abdicate in favour of Lohar Chak. The new ruler too could not hold the reigns of administration well, so chaos and disorder reappeared. The political instability of the territory and selfish role of the nobles forced Yusuf Shah Chak in 1580 to proceed from Thana to Lahore via Jammu for securing the help of Mughal emperor Akbar to regain his lost throne. Akbar without losing the opportunity deputed Raja Man Singh and Mirza Yusuf Khan Rizvi for the purpose. As soon as Yusuf Shah Chak accompanied by the Mughal forces reached Lahore, then he received a proposal from Lohar Chak with the content "If he would return Kashmir irrespective of Mughal forces Lohar Chak would abdicate in his favour."Yusuf Shah Chak being power thirst readily accepted the proposal. He proceeded towards Kashmir with a small force of 3800 men whom he recruited on the way. When he entered the Valley he realized that Lohar Ckak had deceived him as the latter was ready to face the intruder. Despite evil designs of Lohar Chak, Yusuf Shah Chak brushed all hurdles and reached Sopore in November 1580 where he met the deceiver himself. In the episode Lohar Chak was defeated and imprisoned. Thus Yusuf Shah Chak was able to regain the lost throne of Kashmir in 1580 without the Mughal support. This roused the jealousy and anger in the Mughal nobility, who had reinstated Yusuf Shah Chak as the monarch of Kashmir. Consequently Akbar became more enthusiastic to bring Kashmir under his suzerainty ${ }^{6}$.

In 1581 Akbar sent two ambassadors Mirza Tahir and Salih Aqil to the court of Yusuf Shah Chak with a letter to present him personally to the court of Akbar. The ambassadors were given warm welcome by the ruler of Kashmir. He thoroughly discussed the contents of the letter with his advisors, who smell that Akbar wanted to annex Kashmir. Accordingly he dismissed the ambassadors with costly presents along with his third son Haider khan to the court of Akbar. Akbar was not satisfied with this profession of loyalty. He sent Haider khan back to Kashmir in 1582 and was a desirous of Yusuf shah's personal presence. The Sultan got frightened at the repeated Mughal calls. So in 1585 he sent his eldest son prince Yaqoob. Akbar got displeased at this behavior of Yusuf shah to forestall his personal homage. Therefore in October 1585 he sent Bahu-ud-din Kambu and Hakim Ali Gilanee to Yusuf Shah Chak for paying a personal visit to Akbar at Kalanur (Punjab). Prince Yaqoob also informed his father about the Akbar's intention. The situation alarmed the ruler who had consulted his advisors for the same. They urged him for a strong stand but the boss hesitated, hence he showed his inclination to obey Akbar's instructions. Further prince Yaqoob had escaped from the Mughal court, for which Yusuf Shah Chak smell of serious consequences. Owing to these events Yusuf Shah Chak was desirous to accompany the Mughal ambassadors, but was obstructed by his nobles. Therefore the Mughal officials left the Valley empty handed ${ }^{7}$. This had enraged Mughal emperor, who decided to invade Kashmir. On Dec 20, 1585 Raja Bhagwan Das, Mirza Shahrukh and Shah Quli Mahram as instructed by Akbar left with a force of 5000, through Pakhli route. The rebel nobles of Kashmir Haider chak and Sheik Yaqoob Sarfi acted their guides. They met no resistance on the way, as the ruler of Kashmir had not expected the invaders to come from the aforesaid route. The situation discouraged Yusuf Shah Chak to face the mighty Mughals power, but nature defended him as rain, snow storm and scarcity of food supplies took a heavy toll of men and material in the Mughals camp. The condition compelled Raja Bhagwan Das to negotiate for cessation of hostilities. To avoid the future threat as Yusuf Shah Chak smelled in conversation he quietly slipped into the Mughals camp on February 14, 1586 at Buliyasa(Dist.Baramulla) ${ }^{8}$. This approach of the ruler was disliked by his nobles who proclaimed his son prince Yaqoob Shah their new Sultan and continued their struggle against the invader. Though the Mughals in the beginning suffered heavy losses due to stiff resistance offered by the opposite side yet they shortly won over the zamindars of Kuarmast, which weakened the stand of Kashmiris and led to the conclusion of a peace treaty between the two sides. As per treaty Mughals withdrew their forces form Kashmir and Yusuf Shah Chak agreed 
to pay his personal homage to Akbar. Thus the ruler was presented to Akbar at Attack on Mar 28, 1586 by Raja Bhagwan Das who had assured him (Yusuf Shah Chak) of safe return. The emperor not only refused to ratify the peace treaty concluded but also ordered Yusuf Shah Chak to be imprisoned. Though later on Akbar accepted the peace treaty yet the Sultan of Kashmir was not set free. He died in Sept. 1592 and was buried at Biswak, district Patna in Bihar?.

After withdrawal of Mughals from Kashmir prince Yaqoob declared himself free from the treaty obligations and ascended the throne as an independent ruler. Though he assumed the reins of government yet his follies and short sightedness added his difficulties. He showed little respect to his nobles and was merciless towards his subjects. The wretched demeanor of the ruler led to revolts by his nobles and masses. Ultimately a group of nobility led by Shams Chak, Malik Hassan Chadoora, Alam Sher Magre and Ali Dar decided to overthrow the ruler with the assistance of Akbar. Though later on the relation between the nobility and the ruler was pacified yet it was short lived, as religious intolerance led an open contest between the two sides at Sopore where rebels were routed. Due to his victory at Sopore, Yaqoob Shah Chak instructed Qazi Musa for the inclusion of "Ali's" (fourth caliph) name in the Friday prayers Khutba who refused to obey the same for which the Sultan had ordered his execution. The event was intolerable for Sunnis, so Sheik Yaqoob Sarfi escorted by a group of persons approached to Akbar with a request to annex Kashmir forthwith. Consequently Akbar on June 28, 1586 dispatched from Lahore a large force under the command of Qazim Khan. The Mughals while on march through Bhimbhar-Rajouri route secured the help and cooperation of the natives. The ruler of the state came out to oppose the advancing enemy, who met them at Hastivanj, Alibad(Shopiyan).Though in the beginning Mughals were defeated yet they resumed their fight and entered Srinagar with triumph on Oct 14, 1586. Yaqoob Shah Chak the ruler of Kashmir fled to Kishtwar and his associate Shamus Chak to Karnao. After winter they reappeared and made wular pargana and Sopore their respective headquarters where from they made surprise attacks on the Mughals. In 1588 Yaqoob Shah Chak inflicted a crushing defeat on Qazim Khan of the Mughals. This victory encouraged Yaqoob Shah to shift his headquarters from wular pargana to Takht-iSulaiman (Shankar Acharya Hill) Srinagar. The Mughals forces under the able commandership of Qazim khan once again chased Yaqoob Shah Chak at the foot of Takhat-i-Sulaiman and defeated him. Though he received a defeat yet he had not lost hope to succeed. Therefore he extended his hand of friendship to Shams Chak, who together attacked on Mughals where latter suffered heavy loss of men and material. The episode discouraged the Mughals, so Qazim khan had submitted his resignation to the Mughal emperor ${ }^{10}$. Akbar accepted his resignation and appointed Yusuf khan Rizvi a new governor to Kashmir. He succeeded in securing the support of Yaqoob Shah's wellwishers which had weakened his position, so he fled to Kishtwar and his associate Shamus Chak to Brang pargana. Thus Yusuf Khan Rizvi entered Srinagar unopposed and established friendly relations with the locals. He dispatched a strong force against Shamus Chak and chased him to the hills of Kamraj who after wards realized that further resistance against the Mughals is a futile exercise hence he surrendered. He was sent to Akbar who accorded him a fair treatment. Similarly a force was dispatched against Yaqoob Shah Chak who was encamped at Punjyari in Dachun Khover where from he again fled to Kishtwar. In June 1589, Akbar visited Kashmir Yaqoob Shah Chak decided to send his brother Aiba Khan to Emperor Akbar with a petition of apology. Akbar readily accepted his submission. The step led Yaqoob Shah Chak to pay a personal homage to the emperor on July 28, 1589. Subsequently he was arrested and sent to Rohtas in Bihar where he died on Oct.05, 1593. He was buried near his father's (Yusuf Shah Chak) grave. With this ended the long struggle of the Kashmiris to maintain their independence against the Mughals. Hence Kashmir became a part of Mughals Empire as all hurdles were brushed away slowly and steadily. The Mughals ushered in an era of expansion, consolidation and construction. The province of Kashmir as recorded by Abul Fazl in Ain-i-iAkbari was composed of the Valley of Kashmir, Pakhli, Bhimber, Swat, Bijore, Kandhar and Zubulistan with Kabul its capital. But after a brief period the territory assumed its status as a full-fledged province like other provinces of Mughal India. Later on Tibet, Kishtwar, Poonch, Baltistan and Iskardo were brought under Mughal rule. This way the territory shook off the centuries isolation and seclusion. The land functioned as a main Highway of central Asian trade transaction during the period. The province of Kashmir was placed under the control of Subedars (governors) appointed by the central govt. who were responsible to the centre for administrative activities $^{11}$. The Mughals ruled the province for a period of 166years (1586-1752A.D). During which eleven (11) emperors: 
1) Akbar (1586-1605)

2) Jahangir (1605-1627)

3) Shah-i-Jahan (1628-1658)

4) Aurangzeb (1658-1707)

5) Bahadur shah (1707-1712)

6) Jahandar Shah (1712-1713)

7) Farukh siyar (1713-1719)

8) Rafi-ud-darajat (April,1719- june,1719)

9) Rafi-ud-daula (June,1719-September,1719)

10) Mohammad Shah (September,1719-April,1748)

11) Ahmad Shah (1748-1754)

represented by 52 subedars utilized their services. Owing to prolonged warfare and constant mobilization of forces, the economy of the territory was affected badly. Akbar paid his due attention towards streamlining the administration to redress the grievances of the people. He introduced various reforms to bring the administrative and economic setup of the valley at par with other parts of India. The same has been highlighted under the following heads.

\section{Agriculture}

Jahangir in his Tuzki-Jahangiri recorded that out of the total area of the Valley $3 / 4$ was mountainous and $1 / 4$ was arable; the available land was then stratified into various categories. Mirza Haider Dughlat in Tarikhi Rashidi has mentioned four categories of land, Abi, lalmi, Bhagh and Nambal. The Abi land was meant for paddy cultivation. It entailed regular irrigation which was possible in the Valley due to natural springs and streams. Further several canals drawing water from river Jhelum irrigated large tracts of arable land in different corners of the Valley. Though the Mughals had not constructed new canals yet had repaired and maintained the old ones. They appointed a person in every village designated as Mir-i-Aab to render necessary service in every village to distribute the water for irrigation. Due to the abundance of water and its proper usage, the villages and hamlets changed into fertile and highly cultivated tracts. Lalmi land was meant for cultivation of secondary crops including wheat, barley, flax, millet, oats, rapeseed, maize etc. it depended upon periodical rains for irrigation. Bhagh land was to grow fruits and Nambal land was swampy and unfit for cultivation. In addition to it the Valley bounded by forests and Pastoral land provided sufficient grazing for cattle ${ }^{13}$.

The Valley was highly fertile and abundant in numerous agricultural crops. The plough driven by a pair of oxen was of immense importance in breaking hard-clods. The crops such as paddy, maize, pea and millet sown in May-June and reaped in Sep-Oct were categorized as Kharief or autumn crops. The crops sown in OctNov and reaped in April-May were designated as Rabi or spring crops, which generally comprised wheat, barley, pulses and mustard. In short each crop grew under a peculiar geo-physical condition. Vegetables grown all over the Valley such as Lettuce, Turnip, Radish, carrot, Spanish, cucumber, potato, beans and chilly. The cultivators produced a variety of vegetables on a number of floating islands around the Dal Lake, as introduced during the Sultanate period. Further in rural areas every cultivator possesses a vegetable land called "Ver" (kitchen garden) attached to his residence or arable land. The description of agriculture production is incomplete without the mention of fruits for which Kashmir is known from the earliest times. The Mughals made an introduction of grafting as a means to preserve and produce new varieties from those. During the reign of Akbar cherries (shahala) and apricots (zardula) were brought from Kabul by Mohammad Quli Afsher and planted in Kashmir through grafting. Similarly pears, almonds, peach, pomegranate were introduced. Abdul Hamid Lahori in Badshah Nama mentioned that melons of Kashmir were superior to those of Kabul ${ }^{14}$. In addition to it Akbar introduced a new variety "sahibi kishmish". On account of extensive cultivation of the apricots, Baltistan was known as Ts'era Botun. One finds different varieties of fruits available at cheap rates in the Valley.As per sources several areas were specialized in different agricultural products. G.T Veign epitomizes the fact and hold that the wheat of Shahabad, the turnip of Haripur, the rice of Nirpur, the ghee of Pampore, the hemp of Jehamu, the silk of Kotihar are the best in the Valley. This made different parganas of the Valley interdependent in terms of need ${ }^{15}$. Further of all cash crops, saffron was extensively cultivated in Pampore, Inderkote and Kishtwar. Under Mughals vast area was brought under its cultivation, but sugarcane cultivation as introduced by Sultan Zain-ul-Abidin (1420-1470) had vanquished in the period. 


\section{Ownership of Land}

Ownership legally meant the power of total possession, use, disposal and enjoyment held by a person over a determinate thing. By applying the given definition to the source material available on the subject matter, one finds ample scope to establish that in Kashmir people enjoyed private ownership on various items of property both in the urban as well as rural areas between $16^{\text {th }}$ to $19^{\text {th }}$ centuries. Since the arable land was concentrated in the rural areas, the villagers exercised a definite occupancy and cultivating rights which was authenticated by a document during the rule of Shah-i-Jahan (1628-1658AD) ${ }^{16}$. In addition he possessed the right to dispose off. Despite this he faced a practical difficulty in shape of poor land-market i.e. limited money, economy, and abundance of land and shortage of labour. Similarly peasants were left with bare subsistence e.g. $75 \%$ of their agricultural produce was taken away from them by the state and its revenue functionaries. After evaluating the above references one reached to the point that a peasant could not hold the title of Malik (owner) in letter and spirit. In essence it was the state which was the real owner of the land for it enjoyed the optimum benefit of the peasant's labour. Thus one may argue that the apparent legal and fiscal limitations together with practical difficulties, the position of peasants was reduced to a "limited" rather than "absolute" owner of the land in Kashmir. In Kashmir every village represented the features of a diversified socio-economic setup. The concept was rendered possible by the co-existence and interrelation of a host of social groups inhabiting each village which were generally artisans, priests, blacksmiths, carpenters, masons, weavers, potters, oil-pressers, cobblers, peasantry etc. The village officials like makuddam, patwari, shiqdar, sazawol, tarazudar, etc were meant to co-ordinate between the collector and cultivator in relation to guard crops, weigh shares and collect the land revenue. However the peasantry was the most pre-dominant group that contributed to the social formation of the village. Socially the peasantry characterized a homogeneous class but on economic differentiation they were largely stratified into two major catagories, "Asudahahwal" (well-to-do) and "Saqim-ul-ahwal" (indigent). Though all of them were uniformly registered as "Asamis" yet their unlikeliness was profound enough. So the seed and takavi (loans) were distributed among them on their varying economic status. Therefore cultivation in villages was based on individual peasant forming, land was available in plenty to the peasants but to enjoy its fruit remain restricted, as limitations imposed on them led their low standard of life ${ }^{17}$.

In Kashmir land was divided into three divisions:

\section{a. Khalisa \\ b. Jagir \\ c. Madad-i-Mash}

Major revenue used to come from Jagirs and 5\% from Khalisa. In the Khalisa land it was collected by the officials of the state and deposited in the state treasury, but in the jagir land the right of collection was delegated to the mansabdars in lieu of their services. Further land grants conferred upon men of letters, eminent scholars, distinguished poets were not subject to any obligation. Such grants were called madad-i-mash grants ${ }^{18}$.

\section{Industry}

Kashmir is known in the annals of history from ancient times for its artistic zeal. The Valley being land locked and majority of the population lived in rural areas. Therefore they remained busy in agricultural pursuits and agro-based industries like cloth weaving, smithy, carpentry, oil pressing and animal husbandry. The artisans received a share out of the village produce in lieu of their services ${ }^{19}$. As such a village to a greater extent remained self-sufficient in the period. The surplus produce found its way to cities. The flow of village surplus in course of time changed the economic life of the urban dwellers. It is an established fact that the Mughal aristocracy was chiefly urbanized and as such they preferred to live in towns and cities. This led to the expansion of towns in general and city of Srinagar in particular ${ }^{20}$. The urban centers turned into a hub of various types of artisans. During the period arts and crafts received great impetus. It was in the time of Akbar that shawls were manufactured in numerous ranges of price to suit the purse of different classes. During the rule of Aurangzeb it progressed more as these were used by both the sex. Srinagar became its center, where more than 2400 looms were involved in its production which filled the coffers of the territory with money ${ }^{21}$. The skillful artisans were specialized in various techniques and designs. The mode of production, the system of monopolization of resources and markets and concentration of surplus profit in the hands of mercantile community led to the emergence and growth of the capitalist class under whom the artisans manufactured the requisite shawls. This naturally reduced the artisans to a state of semi-bondage, perpetuated by social 
compulsions and lived in wretched plight with their meager wages. Similarly carpet industry parallel to shawl flourished too. Though the industry owes its origin to Sultan Zain-ul-Abidin yet under the rule of Jahangir (1605-1628) through the efforts of Ahmad Beg (governor) was revived. The pile carpets made in Kashmir attained greater perfection and were of floral design with mosques, gardens, wild animals, gliding fish etc. The carpets produced in the Valley were considered superior to those of imported from Persia (Iran) ${ }^{22}$. Barnier, a traveler noted that wood carving flourished at a rapid speed during the period. The specimen of carpenters' art are still extent in the Khatamband ceilings, pinjra or lattice-work as carving in the mosques of Shah-i-Hamdan and Nakshband Sahib in Srinagar. There were state-owned Karkhanas apart from private karkhanas. Besides galichas, dhurries, gabas and other floor carvings were also manufactured. Further a good deal of iron, silver, brass vessels, paper-machie, paper and furniture of delicate nature and boats of different styles were manufactured in the territory. The period opened a way to European travelers. Through their accounts and writings they introduced Kashmir with their novelties to the European world, which in the long run helped in the growth of tourist industry and foreign trade ${ }^{23}$.

\section{MEANS OF COMMUNICATION}

Though the Valley was encircled by lofty mountains yet was pierced by various passes to establish its link with the outside world. The Mughal occupation enhanced the importance of the territory; as they maintained a permanent link of the province with their empire. Abul Fazl in his book Ain-i-Akbari noted that there were (26) routes which linked Kashmir with the rest of world ${ }^{24}$, out of which (6) were regularly used. These routes remained open in winter as well. The Mughals paid their due attention for the maintenance of roads, construction of bridges and establishment of inns, which boosted the trade and commerce of the state. Some of these routes may be introduced in brief as:

a) Mughal road:- This route connected Kashmir with Gujarat. It runs over the Pir-panjal pass via Hastivanj. The important stages on the road were Saidabad, Noushahra, Chingas, Rajouri, Thane, Bahramgalla, Poshiena, Aliabad, Hirapure, Shopiyan, Khampure and Shadimarg where inns were established which turned these places into trade centres of the time.

b) Muzafferabad pakhli route:- this route connected Kashmir with Rawalpindi and Peshawar. The route remained open for the whole year.

c) Poonch route:- the route linked Kashmir through Haji-Pir pass and Tosamaidan pass. Further it linked Jammu via Rajouri.

d) Kishtwar route:- there are two routes leading to Kishtwar from Kashmir, one from Singhpur and another via Dasu. The route connected Kishtwar with Badarwah and Jammu through Ramban. The road was traversed on foot and ponies were also used due to its uneven terrain.

e) Central Asian trade route:- the route passes through Ladakh from east to west. It was passable from March to November, but merchants often used the route due to its commercial importance. It connected Kashmir with Tibet, Kashgar, Yarkand and China. The trade between Kashmir and Bhutan, Nepal, Bengal etc. was also carried on by this route. No doubt the route functioned as an artery to the cottage industry of Kashmir as the entire raw shawl wool was imported through this road. Due to its high elevation and scarcity of fodder, the trade was carried on by the potters on their back, though horses, mules and yaks were also put into service.

f) Navigation: - it was the main source of transport in the Valley, but mules, camels and donkeys were used in hilly tracks and yaks in Tibet. The bulk of trading commodities were carried on the back of potters as wheeled traffic was unknown. There were 7500 boats in Kashmir when Akbar visited the Valley in 1589. The cargo boats were known as Bhats (big boats) and Shikaras (light boats). During the period Akbar introduced new types of boats in Gujarati and Bengali model to accelerate the flow of trade ${ }^{25}$.

\section{Trade}

Trade and commerce played an important role in the economy of Kashmir. It remained a good source of revenue to the state which stimulated manufacturers and gave employment to a reasonable portion of the population. The same poured wealth in the state by its merchants whose commercial activities were connected with Bengal, Nepal, Bhutan, China, Tibet, Iran, Central Asia. The sources revealed that the traders were engaged both in internal and external trade which stabilized the economy of the territory during the period. 


\section{Internal trade}

The continued peace and tranquility in the territory during the period boosted the internal trade. It was carried on in imported as well as locally produced commodities which were salt, luxury goods, shawl, silk, coarse woolen goods and other products of handicrafts. No doubt in predecessors' period (Sultanate) the trade though flourished yet was carried on indoors. The period witnessed a systematic marketing system. Bernier hold that trade in Srinagar was very brisk and the streets were linked with long rows of shops offering various commodities for sale ${ }^{26}$. The same led the development of separate markets e.g. Bazari-Saraffan, Bazari-Baqulla, Bazari-Sabaka. Consequently trade at Anantnag, Sopore, Shopiyan, Awantipore, Baramulla got a flip. The chief means of transport in the Valley was river Jhelum. Potters carried heavy loads over difficult terrain. Pack ponies were used for carrying paddy and other food grains from distant villages to the town market as wheeled carriages were unknown. The rivers were spanned by bridges constructed of stone and timber, that expedite the flow of trade as journey and transaction of goods became easier.

\section{External trade:}

Despite the Valley being land locked, its trade relations with Persia, Central Asia, Russia, Bhutan, Nepal, Bengal and Patna remained excellent, which extended to Bijapure and Golkanda as well. Due to the increasing demand of luxury items by the Mughal nobility and aristocracy the trade flourished tremendously. The route leading to Central Asia via Srinagar remained over busy. The chief commodity of export was shawl. The merchants had monopolized the wool trade in the wool producing regions of Ladakh, Gilgit and Tibet. They had deployed their agents throughout this region to advance loans and collect the shawl wool from the producers. They had established their Warehouse in Chinese Turkistan, Central Tibet, Lahasa, Nepal and Bhutan. In addition to the shawl, floor coverings like carpets, dhuries, printed and embroidered sheets were also sold. Silkworm seeds were imported from Gilgit and China, the silk cloth was exported to India and Central Asia too. Saffron grown in Pampore, Inderkot, Kishtwar was exported to Yarkand, Tibet, China and was even purchased by the English and Dutch merchants. The merchants of Kashmir also delivered the forest products like Saussursa, Lippa (costus), calamus, amberbeads, warmwood to Indian markets like Surat, Ahmadabad etc. Besides these articles various kinds of scent and flowers were also exported which yielded handsome profit to the traders ${ }^{27}$. Further Kashmir remained famous in the production of fine paper. It was in great demand in India which was exported then to Persia. In addition Kashmir imported various articles like salt, shawl wool, cotton cloth, cloves, mace, pepper, turmeric, ginger and sugar. Like wool salt trade too flourished on account of its major consumption. During the period the labourers also received salt as wages. The commodity was brought from Bengal and Thane (Rajouri) turned a salt mandi where from Kashmiri merchants purchased it. The payment for external trade was made by the Hundis. Further all kinds of merchandize were subject to duty or tax e.g. Rs 3 were levied on each shawl exported from Kashmir and Rs 4 on each Trak shawl wool imported. In this context goods imported or exported from Kashmir to Tibet and Yarkand were taxed to the tune of Rs 1 lakh a year payable at Ganderbal Srinagar as recorded during the rule of Aurangzeb. This revealed that goods imported and exported were taxed to supplement the economy which was fundamentally rooted in agriculture ${ }^{28}$.

\section{Coinage}

The monetary system of Kashmir as prevailed during the Hindu and Sultanate periods remained in operation under Mughals as well with slight change in type and weight. The currency under the period consisted of Dinar, Bahagani, Puntsu, Hath, Sasun, lakh, Crore there value was as:
a) 12 Dinars
b) 2 Bahagani

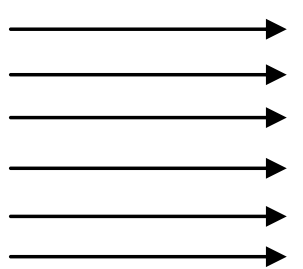
1 Bahagani
1 Pantsu
c) 4 Puntsu
1 Hath
d) 10 Hath
1 Sasun
e) 100 Sasun
1 lakh
f) $100 \mathrm{lakh}$
1 crore (10000000 dinars)

In addition to these there were other types of coins like Ashrafis and Tankas. Akbar had a fine currency in gold and silver. In Srinagar Sarafa Mohalla in Zain Kadal is said to have been the locality of mint in the city. During 
the Mughals it retrained its seat as mint town ${ }^{29}$. The monetary value of the local smaller coins with that of Mughals as given by Abul Fazl in his book Ain-i- Akbari stood as:

a) 1 hath (hundred) = 1 copper dam

b) 1 sasun (thousand) $=10$ copper dam $=1 / 4$ of a Rupee.

c) 1 lakh $($ lakh $)=1000$ copper dam

\section{Weight and measure.}

The units of weight and measurement during the Mughal Period in Kashmir had not under gone to any major change to the prevalent system of Hindu and Sultanate periods which existed as:
1) 16 Mashes = 1 Tola $(11.76 \mathrm{gm})$
2) 80 Tolas $=1$ seer $(940 \mathrm{gm})$
3) $7 \frac{1}{2}$ pols $=1$ seer
4) 5 seer $=1$ Trakh $(4.700 \mathrm{~kg})$
5) 16 Trakh = 1 Kharwar $(76 \mathrm{~kg})$
6) 1 Kharwaar $=80$ seer
7) 1 Gira $=2 \frac{1}{4}$ inches $(5.6 \mathrm{~cm})$
8) 16 Gira $=1$ Gazz $(90 \mathrm{~cm})$

In addition to it Akbar introduced "Men" (mound) which was divided into 40 equal parts called "seer". Though the seer and its subdivisions were standard Mughal weights yet weighing in Kashmir was done in Kharwars and Traks. Even the payment in cash was calculated in kharwars of paddy and the measurement of land in Traks, which was equal to $1 / 4$ of an acre of the present day ${ }^{30}$. However, at present $80 \mathrm{~kg}$ is considered a Kharwar in Kashmir.

\section{Source of Revenue}

In Kashmir land revenue remained the main source of income to the state ex-chequer. The revenue assessment evolved by Shah Mir of the Sultanate period hold good but civil wars in the concluding epoch and external intervention threw it out of gear. The revenue demand under the Sultanate period was $1 / 3^{\text {rd }}$ of the total produce but more was exacted. Further the Jagirdars appropriated the surplus produce from the tenants in shape of illegal cesses. As such cultivators collapsed under the heavy burden of exorbitant taxes. The situation worsened after the Valley got annexed by the Mughals, due to mobilization of forces. Hence this immuned Akbar the Mughal Emperor to send a group of officials namely Sheikh Faizi,Mir Sharief Ahmad,Khawaja Mohammad Hussain,Shams-ud-din and Kanwar Singh to scrutinize the revenue documents of Maraz(South) and Kamraz(North) districts of the Valley. Accordingly he enhanced the rate of revenue lightly, but the Subedar(Governor) of the time exacted more which gave birth to a revolt in 1592 AD led by Mirza Yadgar against the exorbitant exaction ${ }^{31}$. Owing to the incident Akbar utilized the services of another group of officials headed by Asif Khan,who surveyed the whole province and suggested the remedy ${ }^{32}$. Accordingly in 1597 AD Akabar introduced some reforms to ascertain the actual revenue. The new demand was fixed as per the fertility of the land and the span of cultivation ${ }^{33}$. This way he succeeded in evolving a planned revenue settlement. The methods of collection e.g. Nasqi, Galabakhash as introduced by Akbar remained in practical operation throughout the Mughal period. No doubt the tenants were benefitted by the system as were least affected by the fluctuating prices. The burden of drought and flood was borne by both the Parties viz: the cultivator and the assignee, but at the same time it was harmful. The system was expensive as it involved a great number of officials at the harvest to crush the peasants' stability. The presence of Shiqdar at the time of harvesting and thrashing was essential. On one hand the short spanned harvesting season was a domicile sword hanging over the head of the peasant and on the other he had to wait upon the village officials, who proved responsible for the spoilation of produce. The state share was fixed at $1 / 2$ of the gross produce. But the prequisites of land revenue functionaries such as of the Mukaddam, choudhri, qanun go, patwari, shiqdar, and sazawal were also paid by the peasants out of their own share. After meeting all these and other items of village expenditure, the peasants were left with less than $1 / 4$ of their produce, so they were unable to build up their own food stalk hence depended upon the creditors who sucked their blood by imposing high rates of interest on lent. These forces pushed the peasants into destitute ${ }^{34}$. The method thus was a bit disadvantageous both to the state and the peasants. It empowered the Mukaddam to collect the revenue as recorded from his fellow villagers. Further the state recognized the "kashta"(ploughed) land for assessment and not the "uftada"(unploughed) which the peasant

DOI: 10.9790/0837-2202055968 www.iosrjournals.org $66 \mid$ Page


could reclaim without entering in records. Though that too was later on recorded and brought under the revenue net yet much time had passed then and Muqaddams had amassed enormous wealth. Besides salary the revenue functionaries availed certain prerequisites known as "Faruat" and "hububat" which indicated the expenses incurred on the collection of Malia. Further such villages as yielded revenue of 400 kharwars of paddy were bound to pay a cess to revenue functionaries equal to the cost of two goats individually. The zamindars also levied a poll tax called, dastar-shumari (turban tax), Sar-i-darakhti (tax on orchards), Zar-i-dudi (smoke or hearth tax) Telli-chargh (fuel tax) etc. they even were entitled to a share from grown fruits. The peasants also paid Zar-i-niaz (presentation tax) to mansabdars and jagirdars through the village muqaddam. In addition several other sections of the society were brought in the tax net to augment the resources of the state. Baj and Tamgha were realized. Besides Zar-i-nikah (marriage tax) Zari-i-bayutat (tax on building) Zari-i-hasrat (tax on shops) and tax on shawl weavers and hanjis (boat men) were also exacted. In the fiscal exaction by the state the peasants were worst sufferers. An important feature of the period was the emergence of a middle class, who monopolized the woolen textiles, shawl industry and later on the revenue forming as well. Of course the state adopted several measures to ensure greater relief to the peasantry. But in practice all these remained a distant dream. Further jagirdars followed the gruesome policy of exploiting the peasants. In accomplishing their extortionate ends they preferred to demand land revenue in silver and gold without caring about the set traditional mode of payment in kind. As a result the peasantry continued to be fleeced at the hands of unscrupulous subedars, jagirdars and revenue collectors ${ }^{35}$.

\section{CONCLUSION}

The period opened a new chapter in the history of Kashmir as the territory lost its status as a separate entity which it enjoyed upto 1586A.D.The emperors of the dynasty ruled the state through their subedars (governors) who with some exceptions tyrannized and bleed the people by their extortion. The writers and travelers hold that though in the earlier period the land witnessed a change as isolation ended, communal harmony prevailed, trade flourished and industries developed yet in the concluding period it hampered the growth of Kashmirs' in their full stature. The indicators like failure of administrative machinery, disturbance of peace, ignorance of welfare of subjects and torture to peasantry were observed. Consequently these factors led to the disintegration of the empire and passage of the territory from one tyrrant group to another i.e. Afghans in 1753 A.D. Since then the territory passed from one power to another (The Afghans 1753-1819, The Sikhs 18191846 and The Dogras 1846-1947 AD) like a rolling ball under whom it experienced nothing but suffering and pain.

\section{REFERENCES}

[1] M.L. Kapoor,The History And Culture of Kashmir, P.258.

[2] P.N.Tikoo,Story Of Kashmir, P.61.

[3] M.L.Kapoor, opcit, P.259.

[4] A.M.Matoo,Kashmir Under The Mughals, P.05.

[5] M.L.Kapoor,A History Of Medieval Kashmir,P.141.

[6] A. M.Matoo, opcit, P.06.

[7] M.L. Kapoor, opcit, P.259.

[8] Mohibul Hassan,Kashmir Under Sultans, P.177.

[9] A.M.Matoo, opcit, P260

[10] M.L.Kapoor, opcit, P.265.

[11] P.N.K.Bamzai, P.396.

[12] R.K.Parmu,History of Muslim Rule in Kashmir, P.332.

[13] M.A.Kaw,The Agrarian System Of Kashmir, P.58,59.

[14] A.Hamid.Lahori, Badshahnama, Vol.2, P.304.

[15] Irfan Habib,The Agrarian System Of Mughal India, P.60. 
[16] A person namely Malik Haider of village Kangun of Advin Pargana executed a will deed to effect the transfer of his "milkiyest" property among his nephews, which included (4) patts and (6) patts. In Kashmir patta was equal to trak $1 / 4$ of acre.

[17] M.A.Kaw, opcit. P.140-141.

[18] IBID, P.83.

[19] Irfan Habib, opcit, P.60.

[20] A.M.Matoo, opcit, P.223.

[21] Bernier,Travels In The Mughal Empire, P.403.

[22] A.Hamid.Lahori,opcit, P.448.

[23] A.M.Matoo, opcit, P.224.

[24] Abul Fazal, Ain-i-Akbari,Eng.tran.H.Blochmann, P.169.

[25] Alexander Rogers and Henry Beveridge,Tuzki-Jahangiri ,P.295.

[26] A.M.Matoo,opcit, P.223.

[27] Walter.Lawerence,The Valley Of Kashmir, P.78.

[28] Mohammad Azam,Wakiat-i-Kashmir, P.159.

[29] M.L.Kapoor,Kingdom Of Kashmir, P.530.

[30] P.N.K.Bamzai,opcit, P.512.

[31] Alexander Rogers and Henry Beveridge,opcit, P.32.

[32] M.A.Kaw opcit, P.182.

[33] A.M.Matoo, opcit, P.54-55.

[34] M.A.Kaw,opcit, P.160.

[35] IBID, P.318-319. 